Stratigraphy of Upper Pliocene and Lower Pleistocene Marine and Estuarine Deposits of

Northeastern North Carolina and Southeastern Virginia

GEOLOGICAL SURVEY BULLETIN $1502-$ B 


\section{Stratigraphy of Upper Pliocene and Lower Pleistocene Marine and Estuarine Deposits of Northeastern North Carolina and Southeastern Virginia}

By BLAKE W. BLACKWELDER

CONTRIBUTIONS TO STRATIGRAPHY

GE OLOGICAL S URVEY B U L LETIN $1502-$ B

A lithostratigraphic study of marine depositional cycles and their relation to global

climatic changes

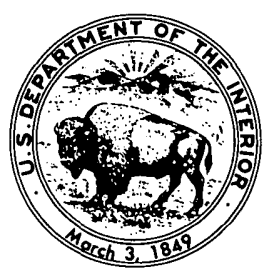


UNITED STATES DEPARTMENT OF THE INTERIOR

GEGIL D. ANDRUS, Secretary

\section{GEOLOGICAL SURVEY}

H. William Menard, Director

\section{Library of Congress Cataloging in Publication Data}

Blackwelder, Blake W

Stratigraphy of upper Pliocene and lower Pleistocene marine and estuarine deposits of northeastern North Carolina and southeastern Virginia.

(Contributions to stratigraphy) (Geological Survey bulletin ; 1502-B)

Bibliography: $p$.

Supt. of Docs. no.: I 19.3:1502-B

1. Geology, Stratigraphic-Pliocene. 2. Geology, Stratigraphic-Pleistocene. 3. Marine sediments-Chowan River watershed. 4. Estuarine sediments -Chowan River watershed. 5. Geology-Chowan River watershed. I. Title. II. Series. III. Series: United States. Geological Survey. Bulletin ; 1502-B.

QE75.B9 no. 1502-B [QE695] 557.3s [551.7'88] 80-607114

For sale by Superintendent of Documents, U.S. Government Printing Office Washington, D.C. 20402 


\section{CONTENTS}

Page
B1
1
2
2
2
7
10
11
12

12
13
15

\section{ILLUSTRATIONS}

Abstract

Introduction

Acknowledgments

Stratigraphy

Chowan River Formation of the Chesapeake Group

Edenhouse Member

Colerain Beach Member

James City Formation of the Chesapeake Group

Flanner Beach Formation

Relation of the Chowan River Formation and the James City

Formation to global climatic trends

[Plate follows "References Cited"]

Plate 1. Mollusks common in the Chowan River Formation.

Figure 1. Map of northeastern North Carolina and southeastern Virginia showing locations of scarps and numbered outcrops of upper Pliocene and lower Pleistocene marine and estuarine deposits

2. Depiction of the type section of the Chowan River Formation and its Colerain Beach Member

3. Photograph of the type section of the Chowan River Formation and its Colerain Beach Member

4. Correlation chart of Pliocene and Pleistocene formations of North and South Carolina Depiction of the type section of the Edenhouse Member of the Chowan River Formation -

6. Schematic cross section of upper Pliocene and lower Pleistocene units: New Bern, N.C., to Norfolk area, Virginia 


\title{
STRATIGRAPHY OF UPPER PLIOCENE AND LOWER PLEISTOCENE MARINE AND ESTUARINE DEPOSITS OF NORTHEASTERN NORTH CAROLINA AND SOUTHEASTERN VIRGINIA
}

\author{
By Blake W. Blackwelder
}

\begin{abstract}
The Chowan River Formation is proposed for marine and estuarine deposits of late Pliocene age that are exposed along the Chowan River in North Carolina. The formation is divided into two units: a lower unit, consisting of marine shelly and silty sand, the Edenhouse Member, and an upper unit, of estuarine clayey, silty sand, the Colerain Beach Member. The Chowan River Formation is bounded by unconformities and represents a distinct marine transgression and regression in the Coastal Plain of northeastern North Carolina and southeastern Virginia. In places, the Chowan River Formation is unconformably overlain by the James City Formation. The James City Formation, a shelly sand and clay, extends from its type area on the Neuse River, N.C., southward to the New River and northward to the Aurora area, where it overlies the Chowan River Formation. I recommend that the term "Croatan Formation" be abandoned, that the upper Pliocene part of the "Croatan" be assigned to the Chowan River Formation, and that the lower Pleistocene part be assigned to the James City Formation. The Chowan River and the James City Formations constitute the uppermost part of the Chesapeake Group.

The Chowan River Formation was deposited during a global warming that followed a period of cooling and ice formation in both hemispheres. The hiatus between the Chowan River Formation and the James City Formation correlates with a cooling trend at the Pliocene-Pleistocene boundary in the Antarctic. The James City was deposited during a transgressive phase that can be related to renewed global warming and ice melting.
\end{abstract}

\section{INTRODUCTION}

Stratigraphic refinement of the upper Pliocene and lower Pleistocene beds of northeastern North Carolina is necessary because of the ambiguous terminology currently applied to these deposits. A major late Pliocene transgression left extensive clastic marine de- 
posits in northeastern North Carolina and southeastern Virginia. These deposits have been variously assigned to formations that were deposited during other transgressive/regressive cycles and that are different lithic entities (for example, Yorktown Formation and "Croatan Formation"). I propose that the name Chowan River Formation be applied to these upper Pliocene beds. Recognition of the Chowan River Formation as a distinct lithic unit enables geologists to describe late Pliocene events in North Carolina more precisely. The Chowan River Formation is divided into two members : the lower, the Edenhouse Member, consists of marine shelly, silty sand; the upper, the Colerain Beach Member, is a sandy, silty, clayey deposit that locally contains trough crossbeds.

The James City Formation (lower Pleistocene) in North Carolina unconformably overlies the Chowan River Formation in the lower Pamlico River (Aurora) area, upper Miocene beds in its type area on the Neuse River, and Oligocene rocks in the New River area. The James City Formation is overlain by the Flanner Beach Formation (upper Pleistocene).

\section{ACKNOWLEDGMENTS}

J. R. Herbert and S. D. Heron, Jr., of Duke University supplied subsurface samples from Core Banks, N.C. L. W. Ward, R. B. Mixon, J. E. Hazel, J. P. Owens, and T. M. Cronin of the U.S. Geological Survey provided help in all phases of this study.

\section{STRATIGRAPHY}

\section{CHOWAN RIVER FORMATION OF THE GHESAPEAKE GROUP}

Mansfield (1943, p. 12) assigned beds along the Chowan River, N.C., to the uppermost part of the Yorktown Formation, even though he recognized that the bed at Mount Gould Landing on the Chowan River is stratigraphically higher than the highest part of the Yorktown in Virginia. Hazel $(1971,1977)$ also recognized that the Yorktown's Chowan River beds at Colerain Landing and Mount Gould Landing are younger than most Yorktown beds in the type area at Yorktown, Va. Ward and Blackwelder (1980) redefined the Yorktown Formation and recognized that the "Chowan River beds" unconformably overlie the Yorktown.

Dall (1892, p. 205, 209) proposed the name "Croatan beds" for units along the Neuse River at Slocum Creek, 15 miles (24 km) below New Bern, and at Mallison's 13 miles $(21 \mathrm{~km})$ below New Bern. At these localities, upper Pleistocene material is well ex- 
posed, but lower Pleistocene beds are poorly exposed. Mansfield (1928, p. 135) and MacNeil (1938, p. 19) recognized that Dall's "Croatan beds" contain both Pliocene (now known to be lower Pleistocene) and Pleistocene (now known to be upper Pleistocene) material and recommended that the Croatan be restricted to the older deposits. MacNeil (1938, p. 19) suggested that the Pliocene (now known to be lower Pleistocene) beds "on the right bank of the Neuse River 2 miles [ $3 \mathrm{~km}$ ] below James City, Craven County, N.C. $* * *$ might be regarded as the type section of the Croatan sand." Because this locality was not even mentioned by Dall (1892) and because these attempts to restrict the use of the term "Croatan" to the older beds were not based on lithic criteria, I recommend that the term "Croatan" be abandoned and that the upper Pliocene part of the Croatan be assigned to the Chowan River Formation of the Chesapeake Group.

The Chowan River Formation is herein named for shelly, silty sand and for laminated and trough-crossbedded sand and silt found along the Chowan River. An exposure $250 \mathrm{~m}$ downstream from Colerain Beach (loc. 1) is designated the type section of the Chowan River Formation (figs. 1-3). The Chowan River Formation pinches out to the south against a structural high at New Bern where lower Tertiary rocks crop out along the Neuse River. In this high area where the Chowan River Formation is absent, beds of the James City Formation directly overlie upper Miocene strata (between locs. 10 and 11). The Chowan River Formation extends northward from the Pamlico River area near Aurora, N.C. (loc. 4), to near Norfolk, Va. (loc. 7), where it consists of shelly marginal marine deposits.

The Chowan River Formation appears to be correlative with or partially younger than the Bear Bluff Formation (fig. 4), a calcareous unit in South Carolina, because both formations contain the mollusks Noetia limula (Conrad, 1832) and Glycymeris subovata of Thomas $(1975, \mathrm{pl} .38$, fig. 7). Both the Chowan River and Bear Bluff Formations lack guide fossils such as the mollusk genera Chesapecten, Ecphora, and Glossus, which are common in the Yorktown Formation. Glycymeris subovata of Thomas (1975) apparently became extinct shortly after deposition of the Chowan River and Bear Bluff Formations. Oaks and DuBar (1974) correlated the Bear Bluff Formation of South Carolina with a Virginia barrier and lagoonal deposit informally termed the "Moorings unit" by Oaks and others (1974). The "Moorings unit" formed when the sea level was $36-37 \mathrm{~m}$ above present mean sea level. Oaks and others (1974) indicated that substantial erosion 


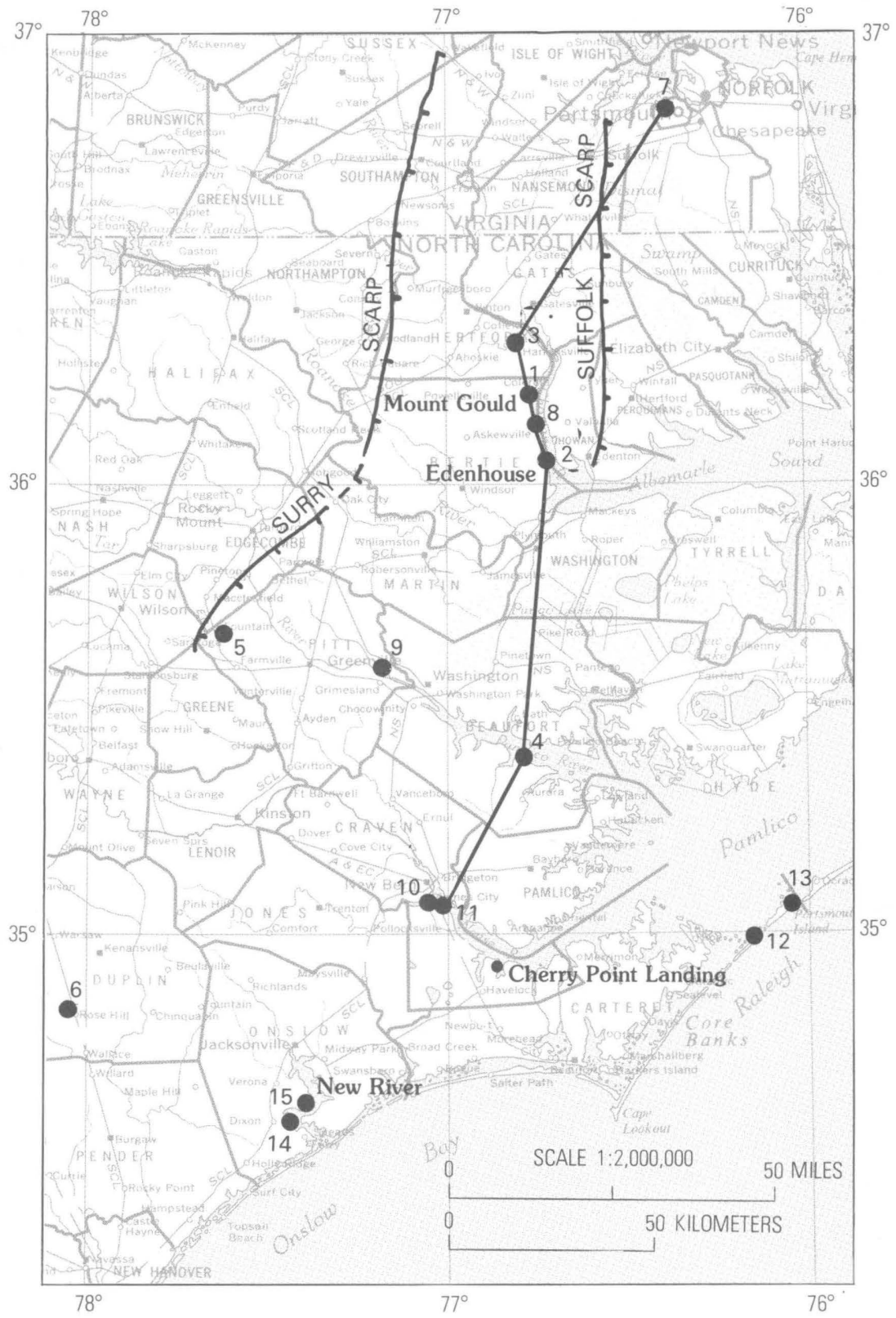

FiguRE 1.-Map of northeastern North Carolina and southeastern Virginia showing locations of scarps and numbered outcrops of upper Pliocene and lower Pleistocene marine and estuarine deposits, and line of generalized cross section (fig. 6). Scarps are shown by lines having hachures on seaward side of cliff face. Outcrops are described in the "Locality Register." 


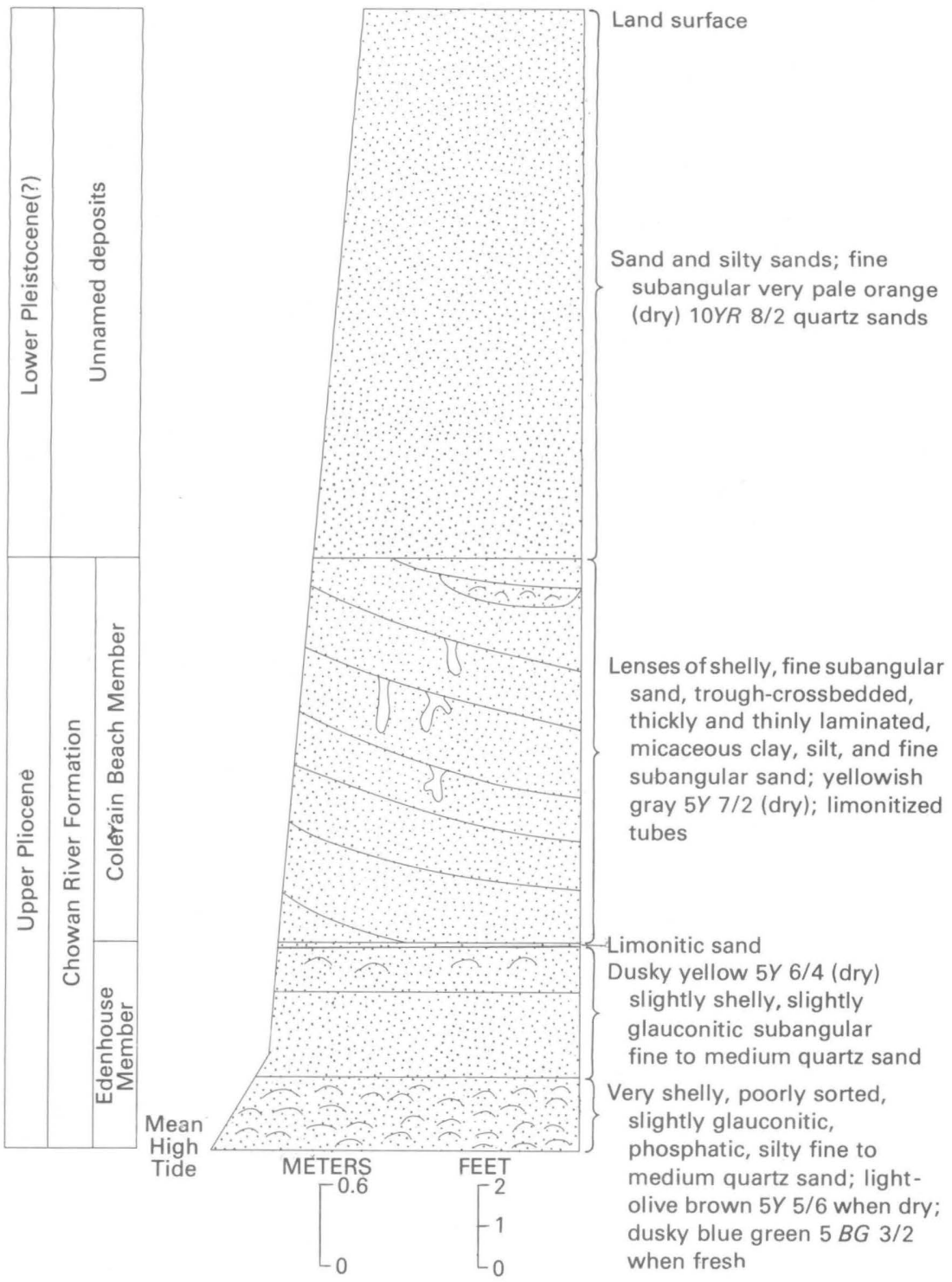

Figure 2.-Type section of the Chowan River Formation and its Colerain Beach Member in bluffs on the Chowan River $250 \mathrm{~m}$ downstream from Colerain Beach, N.C. (fig. 1, loc. 1).

followed the deposition of the "Moorings unit" so that no traces of the deposit remain east of the Surry Scarp.

The Chowan River Formation is divided into a lower unit composed of shelly and silty sand, the Edenhouse Member, and an upper unit composed of sand, silt, and clay, the Colerain Beach Member, defined and described below. 


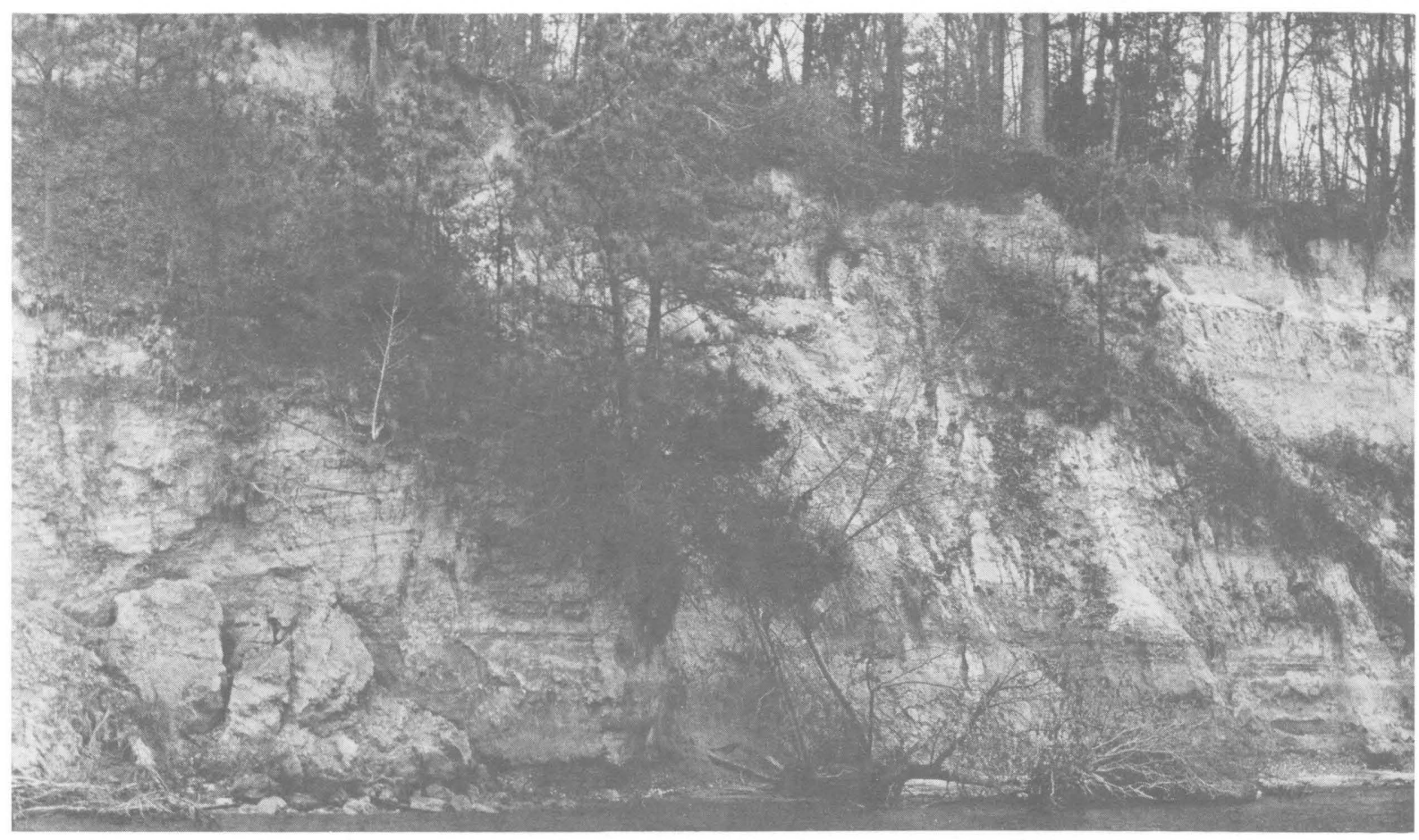

FiguRE 3.-Type section of the Chowan River Formation and its Colerain Beach Member in cliff on Chowan River downstream from Colerain Beach (loc. 1). Lower part of outcrop (Edenhouse Member) is composed of about $0.5 \mathrm{~m}$ of very shelly sand and $1.0 \mathrm{~m}$ of more massive sand containing scattered shells. Steeply dipping trough-crossbedded silty sand of the Colerain Beach Member is visible at left (downriver) end of photograph. Height of cliff is about $10 \mathrm{~m}$. 


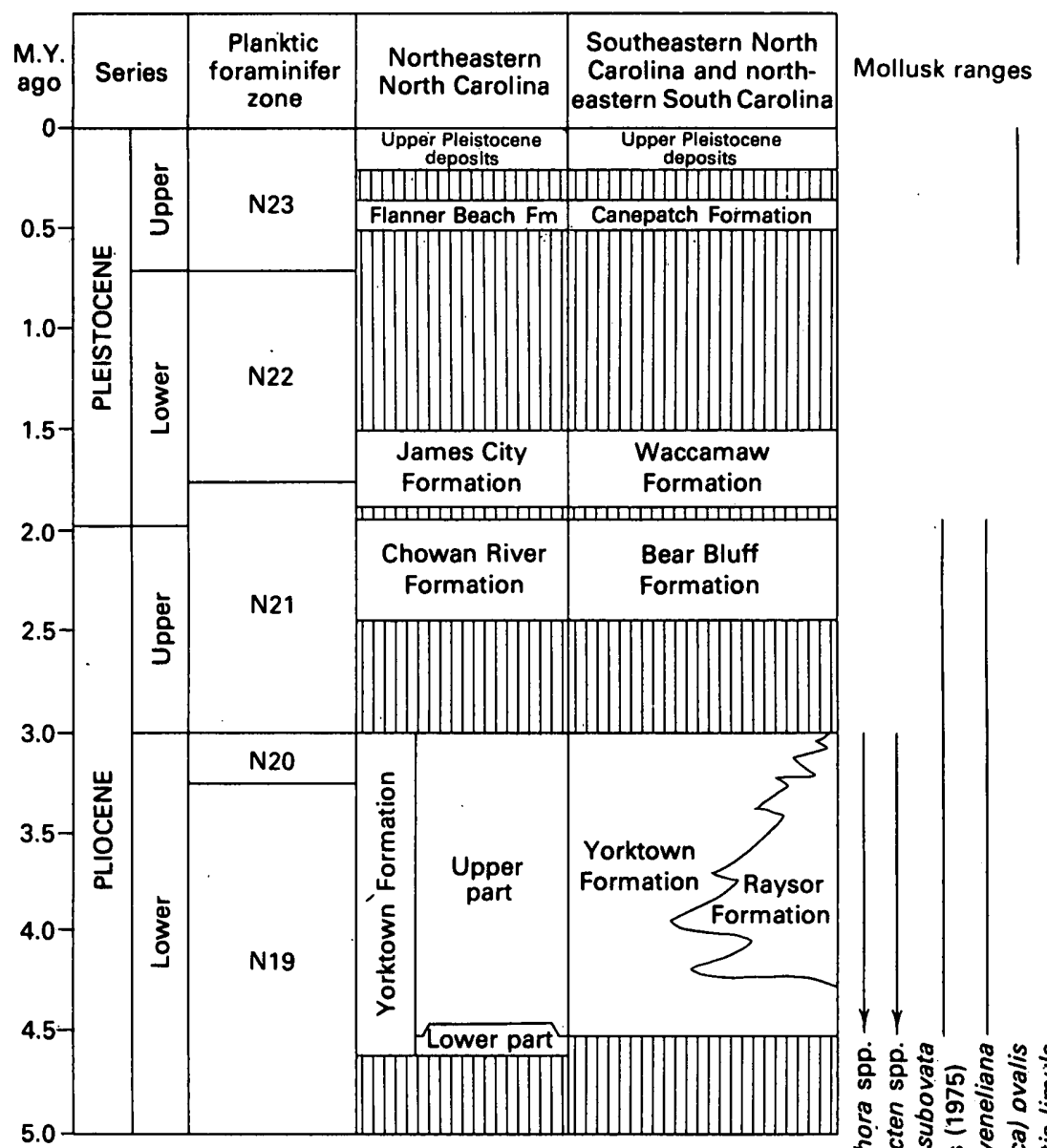

Mollusk ranges 


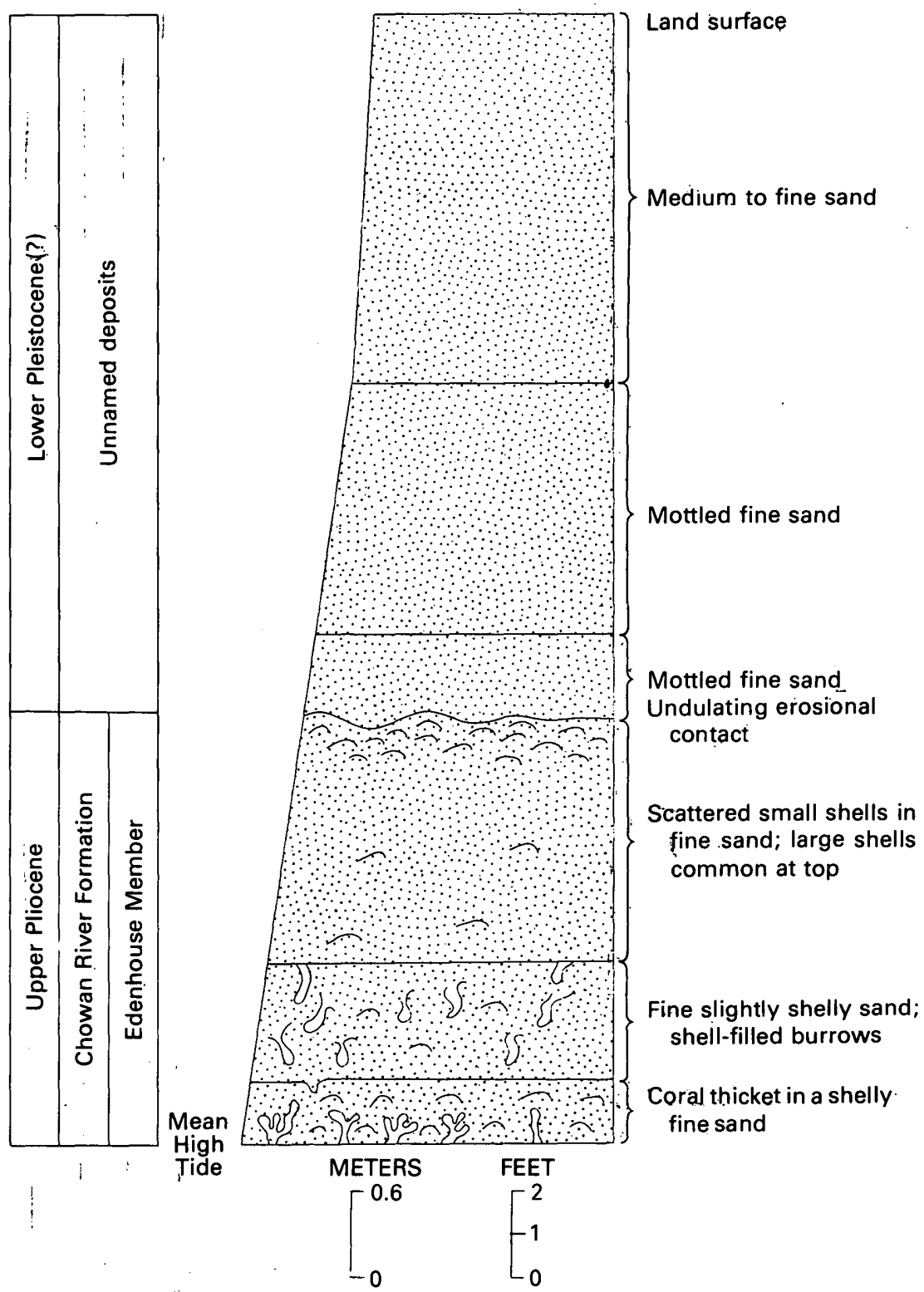

FIGURE 5.-Type section of the Edenhouse Member of the Chowan River Formation in bluffs on Chowan River $1.4 \mathrm{~km}$ upstream from Edenhouse, N.C. (see fig. 1, loc. 2).

the Edenhouse Member of the Chowan River Formation. The section $1.4 \mathrm{~km}$ upstream from the U.S. Route 17 bridge over the Chowan River above Edenhouse (loc. 2) is designated the type 


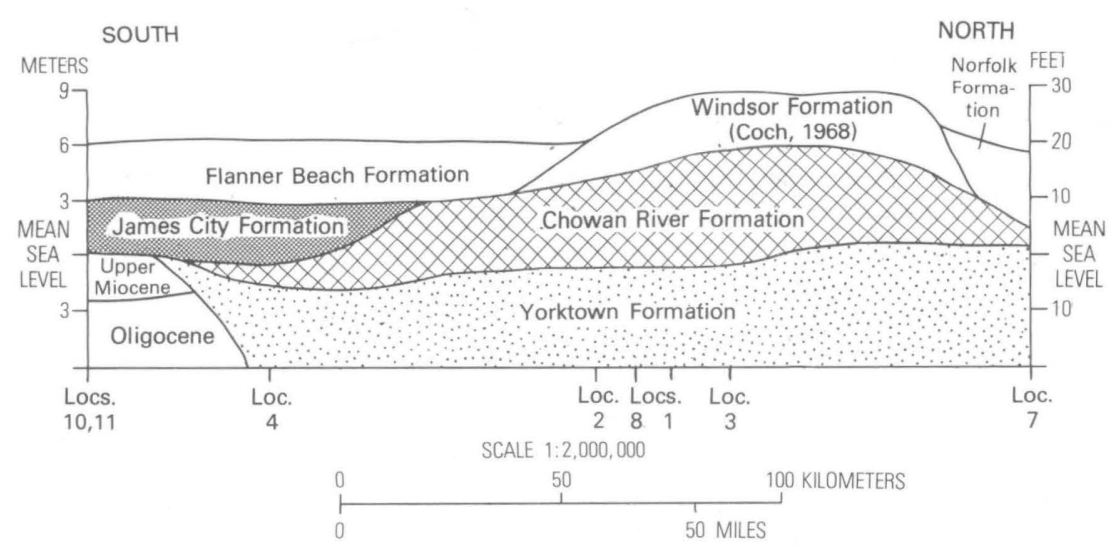

Figure 6.-Schematic cross section of upper Pliocene and lower Pleistocene units from the Neuse River area, North Carolina, near New Bern, to the Norfolk area, Virginia. Localities are described in the "Locality Register."

section for the Edenhouse Member (figs. 3, 5). These shelly sands extend from Tar Ferry on Wiccacon Creek, N.C. (loc. 3), and from Grimesland, N.C. (loc. 9), to near Aurora, N.C. (loc. 4). To the west, these deposits may be found near Fountain, N.C. (loc. 5), and probable correlative beds may also be seen near Rose Hill, N.C. (loc. 6). Hazel $(1971,1977)$ reported beds of Chowan River age at Yadkin, Va. (loc. 7). Figure 6 is a schematic cross section from south to north, showing the relationships of the upper Pliocene and lower Pleistocene beds.

Shelly sands of the Edenhouse Member overlie clays of the Morgarts Beach Member of the Yorktown Formation just upriver from Tar Ferry, Wiccacon Creek, N.C. (loc. 3). Hazel (oral commun., 1978) reported a faunal discontinuity in beds just below water level at Colerain Beach. The faunal discontinuity indicates that the uppermost Yorktown beds (Moore House Member of Ward and Blackwelder, 1980) are missing and that the Edenhouse Member lies directly on middle Yorktown beds (Morgarts Beach Member). At Rose Hill (loc. 6), beds tentatively correlated with this member overlie the Comfort Member of the Castle Hayne Formation (middle Eocene).

In the bluffs on the Chowan River downriver from Colerain Beach, the Edenhouse Member is leached and grades laterally into laminated clays containing very thin (1- to 3-mm-thick) lensoid sand partings. Locally, these silty clays are heavily bioturbated. 
The Edenhouse Member is overlain by estuarine deposits of the Colerain Beach Member. The contact between the two members varies from an apparently transitional contact to one indicating that erosion took place before deposition of the upper member. Near Aurora (loc. 4), the upper part of the Edenhouse Member is partially leached, indurated, and channeled, and beds of the James City Formation lie on this irregular erosional surface. The indurated parts represent the "boulder bed" of Gibson (1967).

Mollusks indicate that the Edenhouse Member represents deposition in shallow marine waters of approximately 15-20 m depth; at Colerain Beach, this unit is a shallowing-upward sequence. The principal mollusk genera include: Argopecten (pl. 1, fig. 2), Glycymeris (pl. 1, fig. 1), Astarte, Abra, Corbula, Cyclocardia, Parvilucina, Nucula, Crassatella (pl. 1, fig. 3), and Crucibulum (pl. 1, fig. 4). Coral is also common. Bailey (1977) discussed the paleoecology of the various biofacies in this member.

Coral from the Edenhouse Member near Mount Gould, N.C., gives a $\mathrm{He} / \mathrm{U}$ date of about 1.91 m.y. (million years) (M. E. Bender, written commun., 1976). Coral from the Chowan River Formation at Lee Creek, N.C. (loc. 4), was dated by Bender at 2.4 m.y. These dates suggest a late Pliocene age for this formation. However, the $\mathrm{He} / \mathrm{U}$ techniques need further testing and may indicate only minimum ages. These two dates on the Chowan River Formation make good sense with respect to the stratigraphy and paleontology (see Hazel, 1977).

\section{COLERAIN BEACH MEMBER}

Trough-crossbedded sand and silt overlying the Edenhouse Member along the Chowan River are herein named the Colerain Beach Member of the Chowan River Formation. The section near Colerain Beach (loc. 1) is designated the type section. The Colerain Beach Member is thickly bedded, although many thin laminations exist with a single bed. Within the crossbeds are large limonitized tubes. Toward the top of the unit, lenses of fossils contain Rangia, Corbicula, and Mercenaria, which indicate estuarine deposition. The brackish-water ostracodes Cyprideis and Cytheromorpha curta are common constituents.

Glycymeris subovata of Thomas (1975) is present, although it is rare and possibly is transported. The presence of Glycymeris subovata, the regressive nature of the deposits, and the gradational contact between the units in some places indicate that the Colerain Beach Member was deposited during the regressional phase of the sea that deposited the Edenhouse Member. The Cole- 
rain Beach Member is believed to be late Pliocene in age because of its close faunal relationship to the underlying Edenhouse Member.

In the type area, the Colerain Beach Member is overlain by crossbedded sand and gravel containing boulders. The contact of the Colerain Beach Member with this gravel is sharp and is at an altitude of about $7.5 \mathrm{~m}$. In places, the current-bedded gravel has been deposited in large channels eroded into the Colerain Beach Member. Because of the substantial erosion of the Colerain Beach Member and because the sand and gravel overlying the member were deposited at altitudes (greater than $22.5 \mathrm{~m}$ ) about as high as those attained by early Pleistocene seas, the sand and gravel are tentatively assigned to the Windsor Formation of Coch (1968). The Windsor Formation in Virginia was named by Coch (1968) for beach, nearshore, and lagoonal coarse sand, pebble gravel, and silty clay and sand that formed when sea level was 24-30 m above present mean sea level. Coch's Windsor was correlated with the Waccamaw Formation by Oaks and DuBar (1974) and is found east of the Surry Scarp in Virginia.

Outcrops of the Colerain Beach Member are known only from the Chowan River area. To the east, this unit has largely been removed by later marine transgressions. Near Aurora (loc. 4), the James City Formation lies directly on an eroded surface of the Edenhouse Member.

\section{JAMES CITY FORMATION OF THE CHESAPEAKE GROUP}

The Chowan River Formation is overlain by the James City Formation of DuBar and Solliday (1963), herein adopted for U.S. Geological Survey usage. DuBar and Solliday (1963) proposed that the name "Croatan Formation" be abandoned because it had been used for two very different and unrelated lithic units. They named these units the James City Formation (now known to be of early Pleistocene age) and the Flanner Beach Formation (of late Pleistocene age). As discussed on page B3, I agree that the term "Croatan Formation" should be abandoned; I recommend that the lower Pleistocene part of the "Croatan" be assigned to the James City Formation.

The James City Formation is recognized to extend from the type area (loc. 11) to outcrops downriver along the Neuse River for about $20 \mathrm{~km}$ to the vicinity of Cherry Point Landing, Craven County, N.C. The James City Formation extends northward to Aurora (loc. 4), where the deposit is very sandy and represents higher energy, less restricted conditions. To the south, the James 
City crops out at low tide on the right bank, near the mouth of the New River, N.C. (loc. 14), where it apparently overlies Oligocene beds that crop out nearby along the river (loc. 15). A unit approximately $30 \mathrm{~m}$ below the surface on Core Banks (locs. 12 and 13) is correlated with the James City Formation on the basis of the mollusks. The James City is correlated with the Waccamaw Formation in southeastern North Carolina and in eastern South Carolina. Akers (1972) recorded Globorotalia truncatulinoides (d'Orbigny) and Globigerinoides obliquus obliquus Bolli from the Waccamaw Formation at Walkers Bluff, N.C. These foraminifers indicate an age of about 1.8 m.y. to $1.6 \mathrm{~m} . \mathrm{y}$. for these beds of the Waccamaw Formation.

\section{FLANNER BEAGH FORMATION}

Fallaw and Wheeler (1969) named beds originally part of the "Croatan sand" as the "Neuse Formation." However, the type section for the "Neuse Formation". is almost directly across the Neuse River, N.C., from the type section of the Flanner Beach Formation (DuBar and Solliday, 1963). As the "Neuse Formation" is the same unit as the Flanner Beach Formation, I propose that the term "Neuse Formation" be abandoned. The Flanner Beach Formation is a well-defined sequence of upper Pleistocene beds on the Neuse River, N.C. Mixon and Pilkey (1976) discussed the distribution of these upper Pleistocene deposits.

\section{RELATION OF THE CHOWAN RIVER FORMATION AND THE JAMES CITY FORMATION TO GLOBAL CLIMATIC TRENDS}

The unconformity between the Yorktown Formation (lower Pliocene) and the Chowan River Formation (upper Pliocene) was caused by erosion during a regression that can be related to global cooling and ice formation. This unconformity apparently coincided with:

1. A cooling event in the equatorial Pacific (Hays and others, 1969), in the Antarctic (Keany, 1978; Hayes and Opdyke, 1967), and in the midlatitudes of the North Pacific dated about 3.8 m.y. to 2.6 m.y. ago (Keller, 1979a).

2. The onset of glaciation in the Northern Hemisphere about 2.6 m.y. ago (Shackleton and Kennett, 1975).

3. Glaciations in Iceland 3.0 m.y. ago (Rutten and Wensink, 1960).

4. Glaciations in the Sierra Nevada in the United States 2.7 m.y. ago (Curry, 1966). 
5. The onset of cooling during the late Pliocene in the Mediterranean area (Thunell, 1979).

6. A cooling in New Zealand before 2.5 m.y. ago (Mathews and Curtis, 1966).

About 3 m.y. ago, the existing Arctic icecap formed (Berggren, 1978).

The Chowan River Formation was deposited during a warming in the midlatitudes of the North Pacific (Keller, 1979a) and apparently predated South American glaciation (Mercer, 1978). The Chowan River Formation was deposited after the early Blancan cold phase discussed by Berggren and van Couvering (1974). This transgression in the Atlantic Coastal Plain probably reflects the worldwide melting of ice during a warm period.

The unconformity between the Chowan River Formation and the James City Formation was caused by erosion during a regression that coincided with global cooling and ice formation. Hays and others (1969) discussed a cooling trend in the Antarctic at the Pliocene-Pleistocene boundary, and Mercer (1978) discussed a thick South American till 2.0 m.y. to 1.86 m.y. old. Keller $(1979 \mathrm{a}, \mathrm{b})$ recorded a significant increase in cool-water foraminifers in the midlatitudes of the North Pacific between 2.2 m.y. and 1.8 m.y. ago.

The James City Formation (lower Pleistocene) was deposited during a transgression that can be related to renewed global warming and ice melting. Keller (1979a) recorded a temperate period 1.8 m.y. to 1.2 m.y. ago in the midlatitudes of the North Pacific. This temperate period took place between cold events. The James City Formation correlates with a warm interval between South American glaciations (Mercer, 1978) and was deposited before a phase of ice rafting in the Atlantic and Pacific and prior to the onset of a prolonged cooling in the Antarctic. The earliest Pleistocene is now generally recognized to have been a warm interval; Selli (1967) suggested that the early Pleistocene in northern Italy represented a preglacial period.

\section{LOCALITY REGISTER (FIG. 1)}

[Left and right riverbanks refer to orientation of person facing downriver.]

1. Right bank of Chowan River, $1.9 \mathrm{~km}$ southeast of Colerain, Bertie County, N.C., $250 \mathrm{~m}$ downriver from the southernmost boat ramp, unmapped quadrangle. Type section of the Chowan River Formation and of its Colerain Beach Member. 
2. Edenhouse, right bank of Chowan River, $1.4 \mathrm{~km}$ upriver from the U.S. Rte. 17 bridge over Chowan River, Bertie County, N.C., Edenton 15-min quadrangle. Type section of the Edenhouse Member of the Chowan River Formation.

3. Tar Ferry, Wiccacon Creek, bluff immediately upriver of landing, $1.2 \mathrm{~km}$ north of Harrellsville, Hertford County, N.C., Winton 15-min quadrangle.

4. Texasgulf, Inc., phosphate pit north of Aurora, right bank of Pamlico River at Lee Creek, Beaufort County, N.C., Bath 71/2-min quadrangle.

5. Auger hole just northwest of Martin Marietta quarry at Fountain, $10 \mathrm{~km}$ north of Farmville, Pitt County, N.C.. Falkland 15-min quadrangle.

6. Billy B. Fussel Company, Inc., quarry, $1.6 \mathrm{~km}$ west of Rose Hill on County Rte. 1102, Duplin County, N.C., Rose Hill 15-min quadrangle.

7. Borrow pits $0.8 \mathrm{~km}$ southwest of Yadkin, City of Norfolk, Va. Near intersection of Portsmouth Ditch and powerlines. Norfolk 71/2-min quadrangle.

8. Right bank of Chowan River, $1.5 \mathrm{~km}$ northeast of Mount Gould, Bertie County, N.C., Edenton 15-min quadrangle.

9. Right bank of Tar River, next to and under County Rte. 1565 crossing of Tar River, $1.8 \mathrm{~km}$ northeast of Grimesland, Pitt County, N.C., Chocowinity 15-min quadrangle.

10. Right bank, lower part of the Trent River, at mouth of Brice Creek, $1.6 \mathrm{~km}$ southwest of James City, New Bern quadrangle, Craven County, N.C.

11. Right bank of Neuse River, New Bern quadrangle, Craven County, N.C., about $2 \mathrm{~km}$ downstream from Fort Point Light. Type section of James City Formation.

12. Portsmouth Bank, N.C., Wainwright Island 71/2-min quadrangle, lat $34^{\circ} 56^{\prime} 40^{\prime \prime} \mathrm{N}$., long $76^{\circ} 11^{\prime} 51^{\prime \prime} \mathrm{W}$. James City Formation at depths of 27.7 to $28.7 \mathrm{~m}$.

13. Portsmouth Bank, N.C., Portsmouth $71 / 2$-min quadrangle, lat $35^{\circ} 4^{\prime} 7^{\prime \prime} \mathrm{N}$., long $76^{\circ} 3^{\prime} 10^{\prime \prime} \mathrm{W}$. James City Formation at depths of 32.9 to $34.4 \mathrm{~m}$.

14. Right bank, New River, 2,000 $\mathrm{m}$ upriver from bridge at Pollocks Point, near stone eccentric marker, Onslow County, N.C. New River 15-min quadrangle.

15. Right bank, New River, at Hines Point, Onslow County, N.C. New River 15-min quadrangle. 


\section{REFERENCES CITED}

Akers, W. H., 1972, Planktonic Foraminifera and biostratigraphy of some Neogene formations, northern Florida and Atlantic Coastal Plain: Tulane Studies in Geology, v. 9, nos. 1-4, p. 1-139.

Bailey, R. H., 1977, Neogene molluscan assemblages along the Chowan River, North Carolina: Southeastern Geology, v. 18, no. 3, p. 173-189.

Berggren, W. A., 1978, Recent advances in Cenozoic planktonic foraminiferal biostratigraphy, biochronology, and biogeography-Atlantic Ocean: Micropaleontology, v. 24, no. 4, p. 337-370.

Berggren, W. A., and van Couvering, J. A., 1974, The late Neogene; Biostratigraphy, geochronology and paleoclimatology of the last 15 million years in marine and continental sequences: Palaeogeography, Palaeoclimatology, Palaeoecology, v. 16, nos. 1-2, p. 1-216.

Coch, N. K., 1968, Geology of the Benns Church, Smithfield, Windsor, and Chuckatuck quadrangles, Virginia: Virginia Division of Mineral Resources Report of Investigations 17, $39 \mathrm{p}$.

Curry, R. R., 1966, Glaciation about $3,000,000$ years ago in the Sierra Nevada: Science, v. 154, no. 3750, p. 770-771.

Dall, W. H., 1892, Contributions to the Tertiary fauna of Florida * * *. Part II, Streptodont and other gastropods, concluded: Wagner Free Institute of Science Transactions, v. 3, pt. 2, p. 201-473.

DuBar, J. R., and Solliday, J. R., 1963, Stratigraphy of the Neogene deposits, lower Neuse Estuary, North Carolina: Southeastern Geology, v. 4, no. 4, p. 213-233.

Fallaw, Wallace, and Wheeler, W. H., 1969, Marine fossiliferous Pleistocene deposits in southeastern North Carolina: Southeastern Geology, v. 10, no. 1, p. 35-54.

Gibson, T. G., 1967, Stratigraphy and paleoenvironment of the phosphatic Miocene strata of North Carolina: Geological Society of America Bulletin, v. 78, no. 5, p. 631-650.

Hays, J. D., and Opdyke, N. D., 1967, Antarctic Radiolaria, magnetic reversals, and climatic change: Science, v. 158, no. 3804, p. 1001-1011.

Hays, J. D., Saito, Tsunemasa, Opdyke, N. D., and Burckle, L. H., 1969, Pliocene-Pleistocene sediments of the equatorial Pacific; their paleomagnetic, biostratigraphic, and climatic record: Geological Society of America Bulletin, v. 80 , no. 8, p. 1481-1514.

Hazel, J. E., 1971, Ostracode biostratigraphy of the Yorktown Formation (upper Miocene and lower Pliocene) of Virginia and North Carolina: U.S. Geological Survey Professional Paper 704, 13 p.

1977, Distribution of some biostratigraphically diagnostic ostracodes in the Pliocene and lower Pleistocene of Virginia and northern North Carolina: U.S. Geological Survey Journal of Research, v. 5, no. 3, p. 373-388.

Keany, John, 1978, Paleoclimatic trends in early and middle Pliocene deepsea sediments of the Antarctic: Marine Micropaleontology, v. 3, no. 1, p. 35-49.

Keller, Gerta, 1979a, Early Pliocene to Pleistocene planktonic foraminiferal datum levels in the North Pacific; DSDP sites 173, 310, 296: Marine Micropaleontology, v. 4, p. 281-294. 
1979b, Late Neogene planktonic foraminiferal biostratigraphy and paleoceanography of the northwest Pacific DSDP site 296: Palaeogeography, Palaeoclimatology, Palaeoecology, v. 27, 129-154.

MacNeil, F. S., 1938, Species and genera of Tertiary Noetinae: U.S. Geological Survey Professional Paper 189-A, p. 1-49.

Mansfield, W. C., 1928, Notes on Pleistocene faunas from Maryland and Virginia and Pliocene and Pleistocene faunas from North Carolina: U.S. Geological Survey Professional Paper 150-F, p. 129-140.

- 1943, Stratigraphy of the Miocene of Virginia and the Miocene and Pliocene of North Carolina, in Gardner, Julia, Mollusca from the Miocene and lower Pliocene of Virginia and North Carolina. Part 1, Pelecypoda: U.S. Geological Survey Professional Paper 199-A, p. 1-19.

Mathews, W. H., and Curtis, G. H., 1966, Date of the Pliocene-Pleistocene boundary in New Zealand: Nature, v. 212, no. 5066, p. 979-980.

Mercer, J. H., 1978, Glacial development and temperature trends in the Antarctic and in South America, in Zinderen Bakker, E. M. van, ed., Antarctic glacial history and world palaeoenvironments: Rotterdam, A. A. Balkema, p. 73-93.

Mixon, R. B., and Pilkey, O. H., 1976, Reconnaissance geology of the submerged and emerged Coastal Plain Province, Cape Lookout area, North Carolina: U.S. Geological Survey Professional Paper 859, 45 p.

Oaks, R. Q., Jr., Coch, N. K., Sanders, J. E., and Flint, R. F., 1974, PostMiocene shorelines and sea levels, southeastern Virginia, in Oaks, R. Q., Jr., and DuBar, J. R., eds., Post-Miocene stratigraphy, central and southern Atlantic Coastal Plain: Logan, Utah State University Press, p. 53-87.

Oaks, R. Q., Jr., and DuBar, J. R., 1974, Tentative correlation of postMiocene units, central and southern Atlantic Coastal Plain, in Oaks, R. Q., Jr., and DuBar, J. R., eds., Post-Miocene stratigraphy, central and southern Atlantic Coastal Plain: Logan, Utah State University Press, p. 232-245.

Rutten, M. G., and Wensink, H., 1960, Paleomagnetic dating, glaciations and the chronology of the Plio-Pleistocene in Iceland: International Geological Congress, 21st, Copenhagen, 1960, Report, pt. 4, p. 62-70.

Selli, Raimondo, 1967, The Pliocene-Pleistocene boundary in Italian marine sections and its relationship to continental stratigraphies: Progress in Oceanography, v. 4, p. 67-86.

Shackleton, N. J., and Kennett, J. P., 1975, Late Cenozoic oxygen and carbon isotopic changes at DSDP site 284-Implications for glacial history of the Northern Hemisphere and Antarctica, in California University, Scripps Institution of Oceanography, La Jolla, Initial reports of the Deep Sea Drilling Project, Volume XXIX ***: Washington, D.C., National Science Foundation, p. 801-807.

Thomas, R. D. K., 1975, Functional morphology, ecology, and evolutionary conservatism in the Glycymerididae (Bivalvia): Paleontology, v. 18, pt. 2, p. 217-254.

Thunell, R. C., 1979, Climatic evolution of the Mediterranean Sea during the last 5.0 million years: Sedimentary Geology, v. 23, p. 67-79.

Ward, L. W., and Blackwelder, B. W., 1980, Stratigraphic revision of upper Miocene and lower Pliocene beds of the Chesapeake Group-middle Atlantic Coastal Plain: U.S. Geological Survey Bulletin 1482-D, 61 p., 5 pls. 


\section{PLATE 1}

Contact photograph of the plate in this report is available, at cost, from U.S. Geological Survey Library, Federal Center, Denver, Colorado 80225. 


\section{PLATE 1}

FIgURE 1. Glycymeris subovata of Thomas (1975, pl. 38, fig. 7)

Length $59.7 \mathrm{~mm}$, height $54.3 \mathrm{~mm}$, width $13.2 \mathrm{~mm}$. Edenhouse Member of Chowan River Formation, $90 \mathrm{~m}$ upriver from loc. 2, upriver from Edenhouse, Bertie County, N.C., from $15 \mathrm{~cm}$ above high tide.

2. Argopecten eboreus (Conrad, 1833)

Length $80.8 \mathrm{~mm}$, height $76.7 \mathrm{~mm}$, width $18.0 \mathrm{~mm}$. From same unit and locality as specimen shown in plate 1 , figure 1 .

3. Crassatella sp.

Length $94.7 \mathrm{~mm}$, height $66.2 \mathrm{~mm}$, width $16.0 \mathrm{~mm}$. From same unit and locality as specimens shown in plate 1 , figures $1,2$.

4. Crucibulum sp.

Dorsal view, maximum diameter $52.8 \mathrm{~mm}$. Edenhouse Member of Chowan River Formation, loc. 4 (U.S. Geological Survey loc. 25364, Lee Creek, N.C.). 

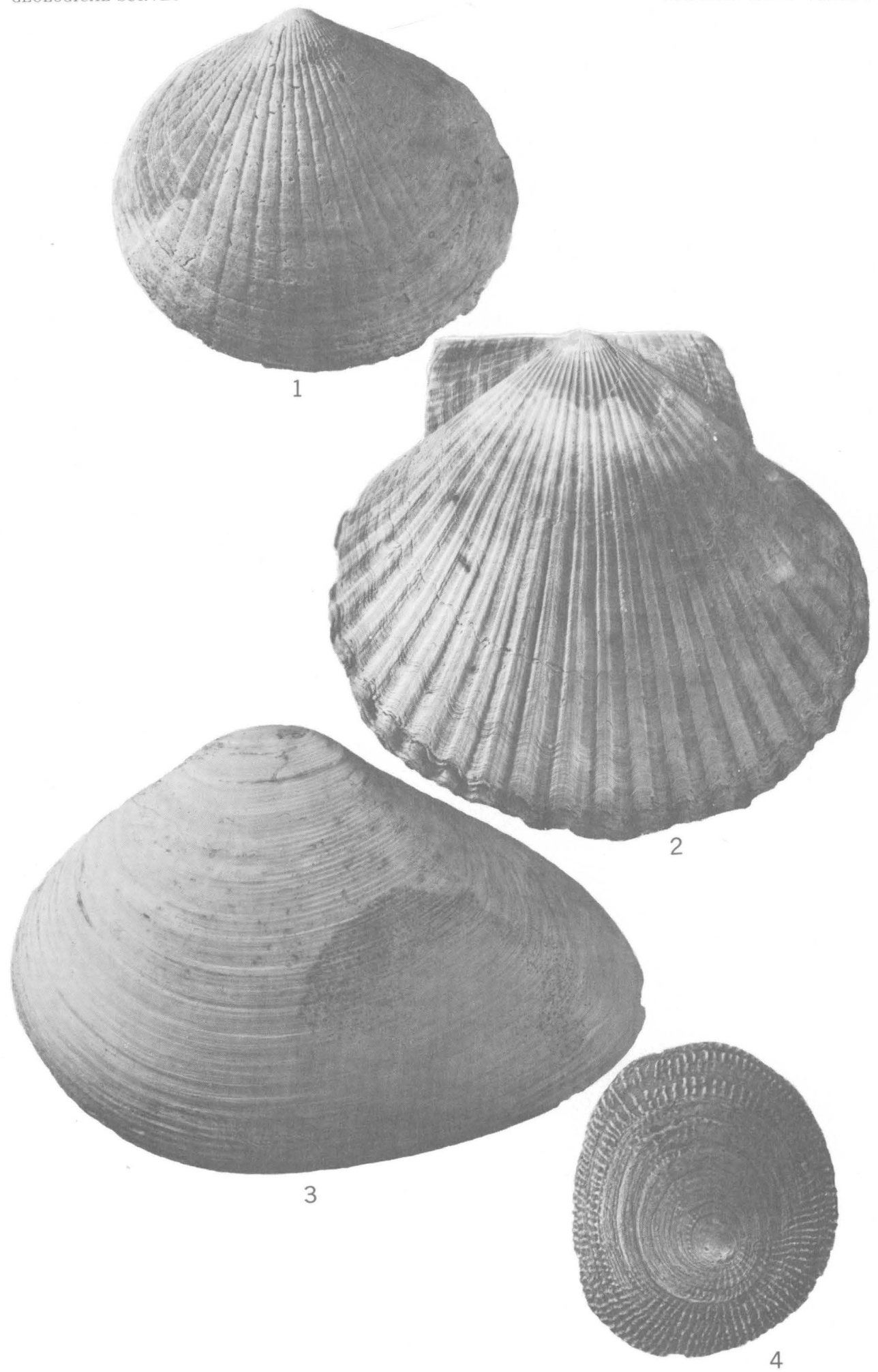

MOLLUSKS COMMON IN THE CHOWAN RIVER FORMATION 